\title{
Production of Bio-Fertilizer through Composting of Tannery Wastes with Cow- Dung and Rice Bran
}

\author{
${ }^{1}$ Lambu, Z.N., ${ }^{2}$ Shamsuddeen, U., ${ }^{2}$ Yahaya, S., 'Aliyu, A.S., ${ }^{1}$ Shehu A.A., ${ }^{1}$ Karfi, A.I., \\ ${ }^{1}$ Isyaku, J., ${ }^{1}$ Mahmud, T. and ${ }^{3}$ Y. S. Mohammed \\ 1 Department of Microbiology, Kano University of Science and Technology, Wudil \\ ${ }^{2}$ Department of Microbiology, Bayero University Kano. \\ ${ }^{3}$ Department of Basic Science, College of Nursing and Midwifery, Kano \\ Corresponding Author Email: zakarinuhulambu@gmail.com Phone: 07032856539
}

\begin{abstract}
Tannery waste is made from nutrients and organic compounds that enhance soil fertility thereby improving plants and microbial growths. This study was designed to investigate the application of tannery wastes to form compost material in a mixture with cow-dung and rice brand. The treatments were prepared and tested for a period of sixty (60) days. The compost was characterized by electric conductivity $(\mathrm{EC})$ of $10.11 \mu \mathrm{s} / \mathrm{cm}, \mathrm{pH}$ of 7.62 and Carbon-Nitrogen (C:N) ratio of 28.8. Total concentrations of Chromium, Lead, Cadmium, Copper, Zinc and Iron in $\mathrm{mg} / \mathrm{kg}$ were $57.2,0.92,12.50,60.50,13.60$ and 1101.00 respectively. However, total bacterial counts decreased from $8.2 \times 10^{8} \mathrm{cfu} / \mathrm{g}$ to $1.8 \times 10^{6} \mathrm{cfu} / \mathrm{g}$ after the 60days. The compost characteristics indicate about $80 \%$ germination index which may suggest the removal of most of the phototoxic compounds.
\end{abstract}

Key words: Composting, Tannery wastes, bio-fertilizer

\section{INTRODUCTION}

Composting is exothermic biological oxidation of various organic wastes in the presence of air and microorganisms, through microbial decomposition, the organic matter is stabilized, matured and deodorized into a product rich in humic substances that can be used as organic soil conditioner (Ouatmane et al., 2000). Many organic waste materials are now being investigated and used as soil amendments in the growth of ornamental and some food crops in many communities, these include composts of yard wastes, sewage sludge, and to lesser extent, municipal solid wastes either singularly or in combination (Gomez-Brandon et al., 2008). There is concern, however, about the presence of toxic metals, polychlorinated biphenyls and asbestos, another waste material, which is commonly used in organic fertilizers as a source of nitrogen, is tannery sludge, a by-product of leather manufacturing (Lisk et al., 1992).

Chromium is both a toxic and essential element for humans and has long been used in the tanning of leather (Mahdi et al., 2007). The resultant fertilizer products may contain extremely high concentrations of heavy metals. Apart from organic materials, which released valuable nutrients on decomposition, tannery sludge may contain pathogens and toxic compounds that poses serious threat to the environment (Anderson, 1981).Aerobic composting or anaerobic fermentation can be applied to reduce pathogens and reduce toxic organic compounds, also composting is a biological aerobic decomposition in which labile organic matter are degraded to carbondioxide $\left(\mathrm{CO}_{2}\right)$, water $\left(\mathrm{H}_{2} \mathrm{O}\right)$, ammonia $\left(\mathrm{NH}_{3}\right)$, inorganic nutrients and stable organic materials like humic substances (Senesi, 1989). This phenomenon has been updated to process organic wastes of different origins, such as sewage sludge, animal manure, agro-industrial wastes (Bernal et al., 1998).

Compost, the generated product, can subsequentlybe applied to increase soil organic matter content, which will release nutrients upon decomposition, and improve soil structure and cation exchange capacity. The objective of this study was to compost tannery wastes with cow manure and rice brand to reduce pathogens and toxic organic components, so that the disposal of tannery wastes into the landfill can be limited while generating a product that can be used to improve soil fertility.

Compost application selectively influences the populations of soil microorganism. The ways of compost influence on the soil microbial community are not fully understood, in many cases, it is not a simple multiplication microorganisms in the compost. 
In contrast, there is evidence that addition of compost promotes the growth of indigenous soil microorganisms (Innebrebner et al. 2006). However, the mechanisms of promotion are unknown in most cases. Also the compost promotes indigenous Bacillus sp. In the soil possibly supply or organic matter activates certain microorganism (Fliessbatch et al. 2006). Composting, when conducted properly, can allow temperatures to reach thresholds high enough to inactivate viruses and parasites in addition to harmful bacteria. (Pourcher et al. 2005) reported that infectious enteroviruses were inactivated after one month of composting sewage sludge - straw mixture.

High temperature is the most important factor for the "Hygienization" (example; elimination of pathogens) of compost (Downer et al. 2008). However not all pathogens have the same sensitivity to high temperature (Bollen and Volker 1996). Effectivity of hygienization depends not only on the maximum temperature achieved within the compost pile, but also on the duration of the heat period (Elorrieta et al. 2006). In addition moisture also interacts with temperature in the hygienization process (Fayolle et al. 2006). Contrary to common belief, high temperatures are not the only mechanism for the hygienization. For example (Elorrieta et al. 2006) showed that the release of phenolic compounds during the process could be responsible for hygienization.

\section{MATERIALS AND METHODS}

\section{Composting}

Dried tannery wastes collected from Unique leather industry in Saharada, Kano, Nigeria was used for this research.

An in vessel (pit) type of compost was used and consisted of approximately $5000 \mathrm{~kg}$ of tannery wastes, rice bran, and cow manure at ratios of $1: 3: 1$. The initial moisture content of the composition was $60 \%$ and composting cycle lasted for sixty days. The pits were turned after every five days to maintain adequate aeration and to minimize odor production. Subsequently, samples for physicochemical and heavy metals analysis were systematically taken at the end of every ten days of the composting process and air-dried for a period of another ten days. The dried samples were separately ground down into fine powder as described by Mahdi et al., (2007).

Physicochemical analysis

The temperature was measured in triplicate during mesophilic, thermophilic and maturation phases of composting using mercury in glass thermometer at the composting sites. Moisture content of the composts were determined after ovendrying the samples $(10 \mathrm{~g}$, fresh weight) at $105^{\circ} \mathrm{C}$ for $24 \mathrm{~h}$. Total carbon was determined by dry combustion at $550^{\circ} \mathrm{C}$ and total $\mathrm{N}$ content (TN) by the Kjeldahl digestion analysis. $\mathrm{pH}$ and electrical conductivity (EC) were measured in aqueous extracts $(1: 10, \mathrm{w} / \mathrm{v})$ using a $\mathrm{pH}$ meter (HD8602, Italy) and a conductivity meter (CC401 ELMEIRON, Poland), respectively. Samples were analyzed in triplicate. Micro nutrients and heavy metals were analyzed by Atomic Absorption spectroscopy (AAS) as described by Eno et al. (2009).

Isolation and identification of bacteria

Bacteria were isolated from the composts by serial dilution from $10^{5}$ to $10^{8}$ and in duplicated Petri dishes were plated and labeled accordingly from each of the mesophile (30 and $\left.35^{\circ} \mathrm{C}\right)$, thermophile $\left(40\right.$ and $\left.70^{\circ} \mathrm{C}\right)$, maturation and cooling phases ( 35 and $30^{\circ} \mathrm{C}$ ) using nutrient agar (NA). The plates were incubated at $30^{\circ} \mathrm{C}$, $35^{\circ} \mathrm{C}, 40^{\circ} \mathrm{C}$ and $70^{\circ} \mathrm{C}$ for $24 \mathrm{~h}$ to represent the respective phases. Colonies were counted and expressed in $\mathrm{cfu} / \mathrm{g}$. Isolates were purified and preserved accordingly. The samples were collected during morning's hours, afternoon and evening hours. Presumptive identification was carried out by colony morphology, and gram reactions.

\section{Compost Maturity Test}

The physical and chemical method of compost maturity/stability including color and odor changes, texture, $\mathrm{C}: \mathrm{N}$ ratio, germination index and temperature were adopted (Zucconi et al., 1981).

\section{Germination index}

Germination index were determined according to the method of Zucconi et al., (1981) ten grams $(10 \mathrm{~g})$ of all the screen samples were shaken with $100 \mathrm{ml}$ of distilled water for an hour. The suspension was centrifuged for 15 minutes at $300 \mathrm{rpm}$ and supernatant was filtered through a filter paper. Ten seeds of beans (Vigina unguiculata) were placed on filter paper in a petridish. Two milliliter $(2 \mathrm{ml})$ of the extract was added to the Petri dish. Two milliliter $(2 \mathrm{ml})$ of distilled water was also used for control. The test was ran in triplicate. Petri dishes were left on the laboratory bench and after 48 hours, the total length of each beans root was measured. If the seed was did not germinate their root length was considered to be $0 \mathrm{~mm}$. the germination index is given as percentage based on the total length of root on the test plate $\times 100$ divided by total length of the root of the control plate.

Carbon Nitrogen Ratio (C/N)

Organic carbon content was determined using the method described by Walkley and Black, (1934). While total nitrogen (N) were 
determined by micro-kjedahl method. While, colour change were accessed by visual observation and odour through olfactory judgment as adopted by Pan and Sen, (2013).

\section{RESULTS AND DISCUSSION}

Physicochemical properties of the raw materials used for composting

The results of the physicochemical properties of tannery sludge, rice bran and cow manure used for the composting are presented in (Table 1). The cow manure was the lowest in $\mathrm{C} / \mathrm{N}$ ratio (25.96) followed by rice bran and tannery sludge with the ratio of 59.14 and 28.81 respectively. The EC of the substrate were $(10.11,8.00$ and 6.950$) \mu \mathrm{s} / \mathrm{cm}$ for the cow dung, rice bran and tannery sludge respectively. The tannery wastes showed that the level of chromium was higher $(52.20 \mathrm{mg} \mathrm{kg})$ in tannery sludge. The $\mathrm{pH}$ of cow manure and rice bran were acidic (5.71 and 6.90) while that of tannery wastes was alkaline with the value of 7.62 .

The results above is poorly presented, figure were shown and referred to. A better way of doing this is to describe the values as high, medium or low and show the maximum tolerable limits. Clarity of language is key here. Temperature changes

In this study, three different temperature phases were observed for the different composting pits (Figure 1). The initial mesophilic phase $\left(25-40^{\circ} \mathrm{C}\right)$ lasted for 4 days in Tannery sludge, Rice bran and Cow manure (TRC), Tannery sludge and Rice Bran (TR) while 24 days for Tannery sludge only (T). Thermophilic phase $\left(40-70^{\circ} \mathrm{C}\right)$ lasted for 28,22 and 10 days for TRC, TR and T respectively. Maturation phase also lasted for 20, 24 and 14 days for the TRC, TR and $T$ respectively

Table 1: Physico-chemical Characteristics of Tannery Sludge, Rice Bran, and Cow dung composts

\begin{tabular}{|c|c|c|c|}
\hline Characteristics & Tannery sludge & Cow manure & Rice bran \\
\hline $\begin{array}{l}\text { Ph } \\
\text { E.C }(\mu \mathrm{s} / \mathrm{cm}) \\
\text { C:N } \\
\text { Heavy metals } \\
\text { Fe }(\mathrm{mg} / \mathrm{kg})\end{array}$ & $\begin{array}{l}7.62 \pm 0.1^{\mathrm{a}} \\
10.11 \pm 0.1^{\mathrm{a}} \\
28.81 \pm 0.2^{\mathrm{a}}\end{array}$ & $\begin{array}{l}5.71 \pm 0.026^{\mathrm{b}} \\
69.50 \pm 0.021^{\mathrm{b}} \\
25.96 \pm 0.62^{\mathrm{b}} \\
620.20 \pm 0.56^{\mathrm{b}}\end{array}$ & $\begin{array}{l}6.90 \pm 0.01^{c} \\
8.00 \pm 0.02^{c} \\
59.14 \pm 0.03^{c} \\
140.00 \pm 3.03^{c}\end{array}$ \\
\hline $\mathrm{Cu}(\mathrm{mg} / \mathrm{kg})$ & $60.50 \pm 0.09^{a}$ & $20.10 \pm 0.04^{\mathrm{b}}$ & $22.47 \pm 2.01^{c}$ \\
\hline $\mathrm{Pb}(\mathrm{mg} / \mathrm{kg})$ & $0.92 \pm 0.01^{\mathrm{a}}$ & $2.4 \pm 0.05^{\mathrm{b}}$ & $9.50 \pm 0.09^{c}$ \\
\hline $\mathrm{Cd}(\mathrm{mg} / \mathrm{kg})$ & $12.50 \pm 0.02^{\mathrm{a}}$ & $1.50 \pm 0.01^{\mathrm{b}}$ & $0.7 \pm 0.01^{c}$ \\
\hline$M(\mathrm{mg} / \mathrm{kg})$ & $82.40 \pm 0.67^{\mathrm{a}}$ & $13.60 \pm 0.02^{\mathrm{b}}$ & $27.30 \pm 0.02^{c}$ \\
\hline $\mathrm{Zn}(\mathrm{mg} / \mathrm{kg})$ & $130.60 \pm 0.29^{a}$ & $126.50 \pm 0.02^{\mathrm{b}}$ & $40.00 \pm 0.03^{c}$ \\
\hline $\mathrm{Cr}(\mathrm{mg} / \mathrm{kg})$ & $57.20 \pm 0.36^{a}$ & $2.60 \pm 0.02^{b}$ & $5.82 \pm 0.01^{c}$ \\
\hline
\end{tabular}

Values are mean \pm S.D, values with different super scripts within the same row are considered significantly different $(P<0.005)$.

Key: Canadian Std. of Biosolud = Canadian Standard of Biosolid

Significant differences were evident in the temperature changes among the three different compositions. Long thermophilic phase which lasted for 26 and 22 days could be as a result of higher microbial activities and availability of degradable organic compounds as reported by Nurul Ain et al. (2014). The results obtained in this research suggests that co-composting of tannery sludge with rice bran and cow manure accelerated the composting processes as reported in Diaz et al. (2002). The findings are also in agreement with those of Boultere-bitzer et al. (2006) in which four different composts from mixtures of husk, chicken and paunch manure, bone meal ash, nark mix, soya bean meal and milogranite were found to be increasing the temperature within 10 days. Such increase was recorded from ambient temperature to a range of $55-70^{\circ} \mathrm{C}$ after 31 days of composting prior to the cooling phase. The peak temperature for the TRC, TR and T were $72^{\circ} \mathrm{C}, 70^{\circ} \mathrm{C}$ and $51^{\circ} \mathrm{C}$ at day 24,22 and 40 respectively. 
pH changes

The $\mathrm{pH}$ value during the mesophilic phase were 7.3, 7.3 and 7.23 for TRC, TR and T respectively. While for thermophilic phase the $\mathrm{pH}$ were 7.4, 7.5 and 8.21 for TRC, TR and T respectively. Moreover, for the maturation phase the $\mathrm{pH}$ value were $6.9,6.9$ and 7.46 for TRC, TR and $\mathrm{T}$ respectively. The $\mathrm{pH}$ values recorded in each composition were within the range of 6.9 - 8.5 during the composting processes (Figure 2). Specifically, this $\mathrm{pH}$ rise from mesophilic to thermophilic was more pronounced for Pit three (tannery sludge only) than for the two co-composted piles $(P<0.05)$. The difference in $\mathrm{pH}$ values may be due to the different starting material and different treatment used for the research as suggested by Zhu et al. (2007). The pH value of different compost piles increased minimally at the start of the experiment to alkaline values at thermophilic stage.

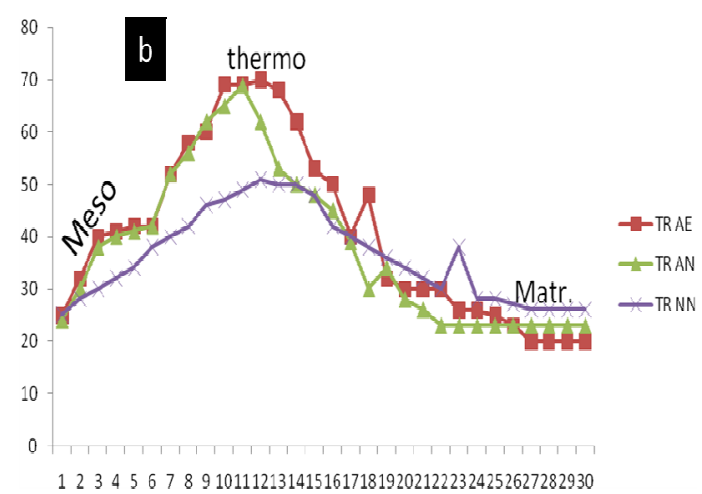

123456789101112131415161718192021222324252627282930
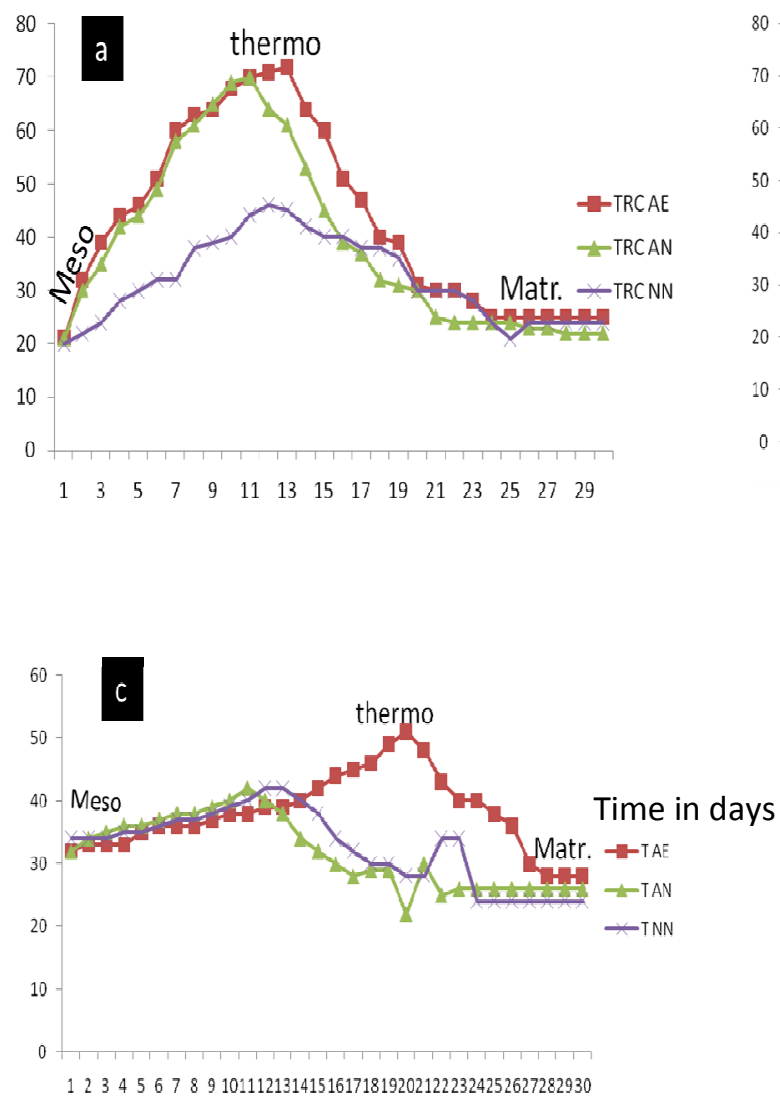

Figure 1: Temperature Changes during Composting. $a=$ Treatment One (Aeration plus Effectors Microorganism), $b=$ Treatment two (aeration only), $c=$ Treatment three (no aeration and no effector microorganism).

This could be due to the production of more ammonia during ammonification and mineralization of organic nitrogen in tannery sludge. Between thermophilic and maturation phase, $\mathrm{pH}$ values were found to decrease minimally. The increase in $\mathrm{pH}$ over composting phase can be attributed to a release of ammonia associated with protein degradation, and its subsequent decrease to a volatilization of ammonia nitrogen and $\mathrm{H}+$ release resulting from a microbial nitrification process (GómezBrandón et al., 2008). The presence of volatile fatty acids may also influence the $\mathrm{pH}$ development in the compost pit, as reported in previous studies (Beck-Friis et al., 2001). The dynamics of fatty acid formation and decomposition seem to be important in controlling biological activity and in turn, the gaseous emissions during the composting process. Fekedu et al., (2014), observed that, when the thermophilic phase began in the selfheated household waste compost, fatty acids were decomposed followed by a rapid increase in $\mathrm{pH}$ and $\mathrm{NH} 3$ emissions. 


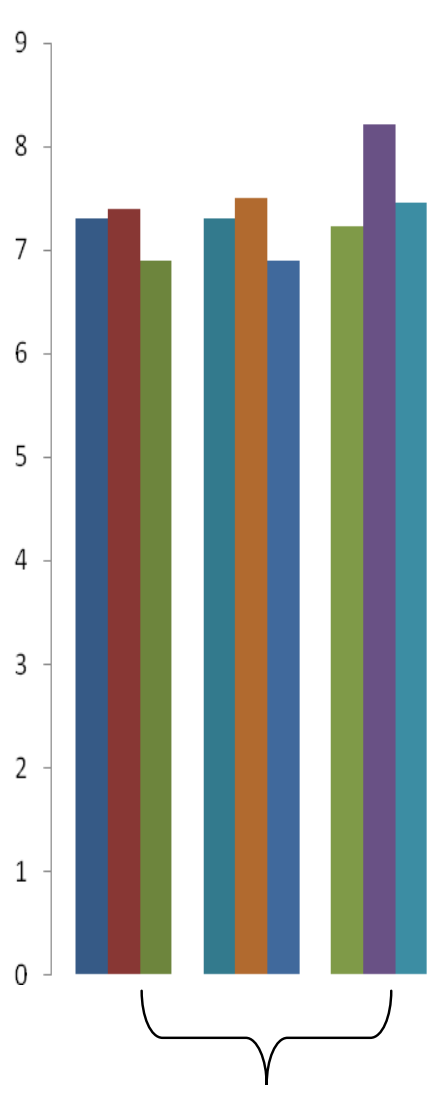

Treatment 1 (AE) TRC, TR

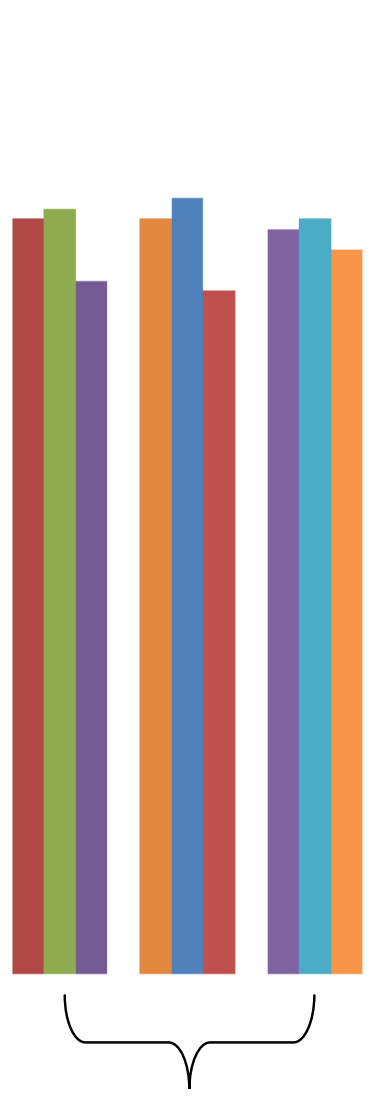

Treatment 2 (AN) TRC, TR

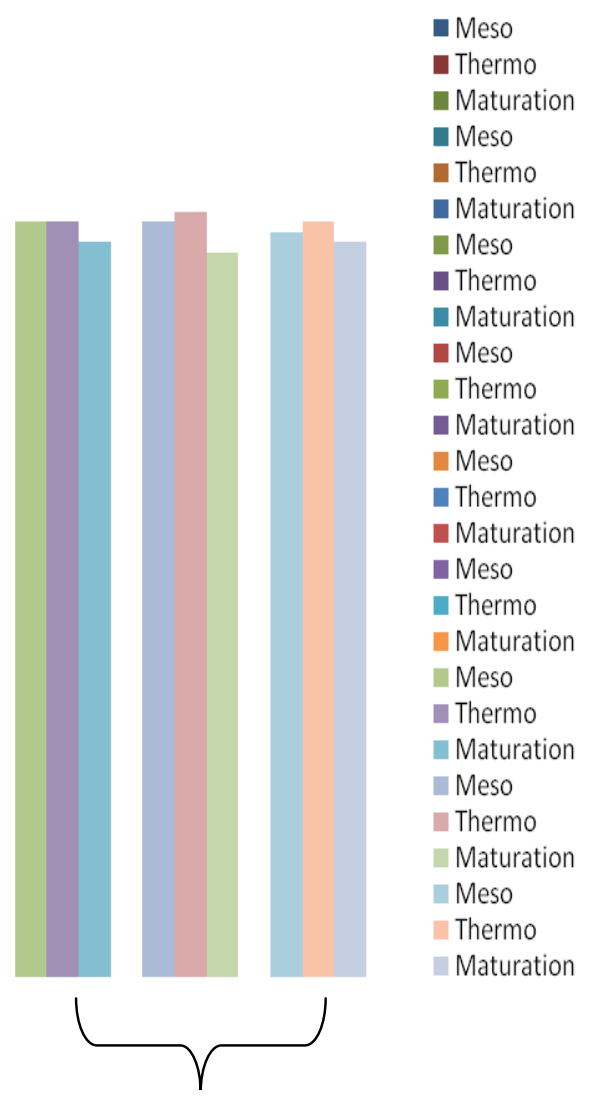

Treatment 3 (NN) TRC, TR

Figure 2: pH Changes at Mesophilic, Thermophilic and Maturation of the Biomass (TRC, TR and T) with Different Treatment

\section{Changes in electric conductivity}

The EC values during the mesophilic phase were 3.0, 2.9 and 4.0 for TRC, TR and T respectively. While for thermophilic phase the EC were 2.7, 2.6 and 3.8 for TRC, TR and T respectively. Moreover, for the maturation phase the $\mathrm{EC}$ value were 2.7, 2.8 and 3.2 for TRC, TR and T respectively.

Electric conductivity (EC) increased significantly in all the treatments from the starting of experiment (Figure 3 ). This could be due to the release of ions, such as phosphate, ammonium and potassium throughout the composting process. Bernal et al. (2009) reported increase in EC during mesophilic phase and decreased after mesophilic and maturation phase. Composts had EC values suitable for soil application value of $3 \mathrm{mScm}{ }^{1}$ (Gomez-Brandon et al., 2008). Compost treatment using cow manure showed higher trend of electric conductivity values compared to the treatment without cow manure, this is because microbial biodegradation of the organic manure releases salt from the manure. The results obtained are in agreement with Irshad et al., (2013), which showed increase in level of EC for goat manure composting around $10.4 \mathrm{ds} / \mathrm{m}$ to $10.6 \mathrm{ds} / \mathrm{m}$, during manure composting. NurulAin et al. (2011) reported that compost treatment using goat manure showed higher trend of EC values compared to the treatment without goat manure. 


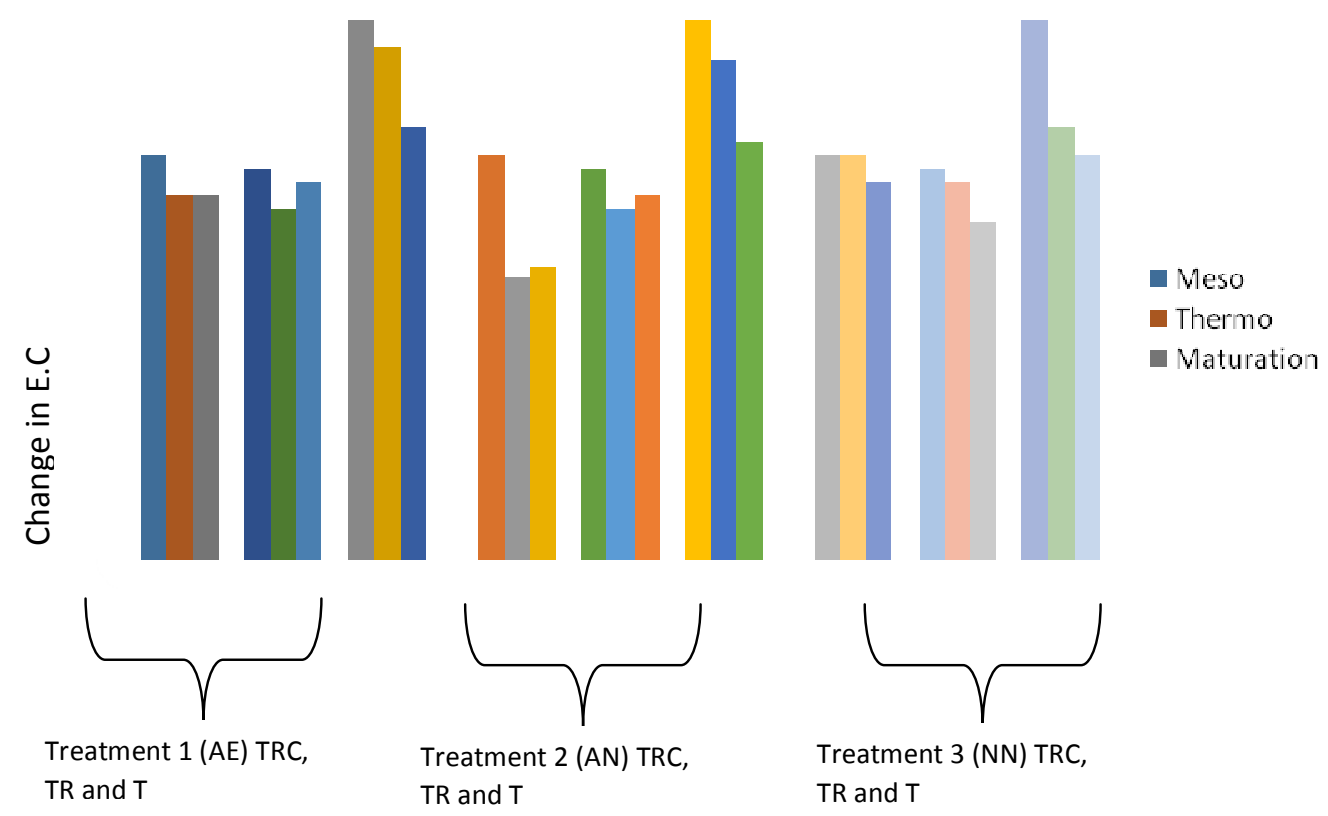

Figure 3: E.C $\left(\mathrm{mScm}^{-1}\right)$ Changes at Mesophilic, Thermophilic and Maturation of the Biomass (TRC, TR and T) with Different Treatment

\section{Changes in Carbon Nitrogen ratios (CN)}

The $\mathrm{CN}$ ratio decreased significantly over the phases, of composting especially in the cocomposted piles (Figure 4). As Carbon was lost in the form of $\mathrm{CO}_{2}$ through microbial respiration and $\mathrm{N}$ nitrogen was recycled (Ryckeboer et al., 2003). A much low $\mathrm{CN}$ ratio and high offensive odor at the end of the composting process for the tannery sludge compost ( $T$ ) was found, this indicates rapid biodegradation process in this compost. The addition of cow manure and rice bran to tannery sludge, however, significantly contributed to the decomposition of the lignocellulosic compounds of the rice bran, resulting in decrease $\mathrm{N}$ losses; in these mixed composts, this is in agreement with the finding of Sánchez- Monedero et al. (2001).

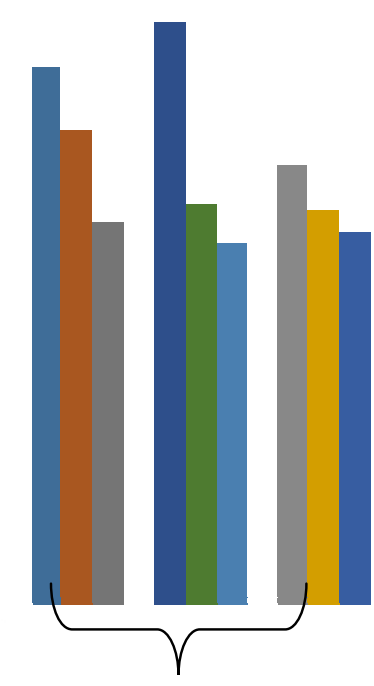

Treatment 1 (AE) TRC, TR

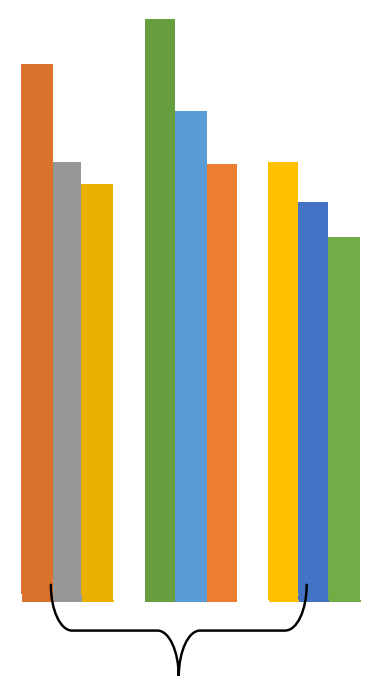

Treatment 2 (AN) TRC, TR

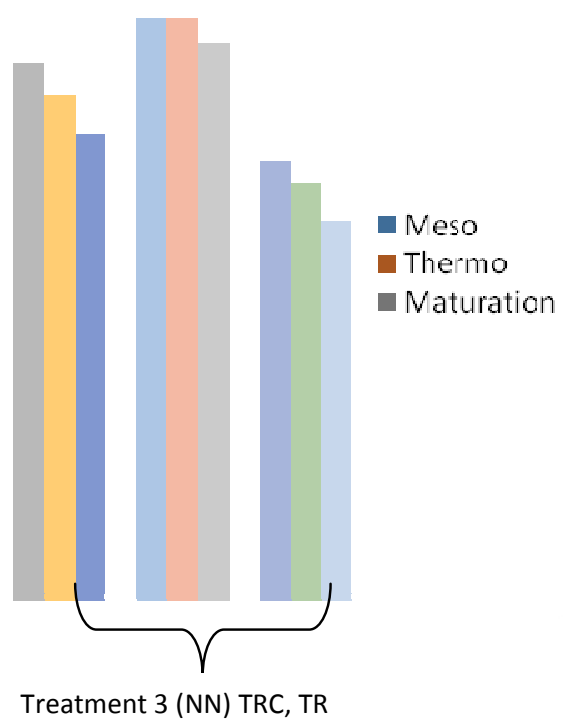

Treatment 3 (NN) TRC, TR

Figure 4: Carbon Nitrogen Ratio Changes at Mesophilic, Thermophilic and Maturation of the Biomass (TRC, TR and T) with Different Treatment 


\section{Changes in bacterial population during composting}

The aerobic mesophilic counts of bacteria in the three different compost piles indicated significant variations in relation to temperature changes during the composting process (Figure 5-6). At the mesophilic phase of the process, high numbers of bacteria were found in pit one (TRC) $\left(8.2 \times 10^{8} \mathrm{cfu} / \mathrm{g}\right)$ and Pit two $\left(5.2 \times 10^{7} \mathrm{cfu} / \mathrm{g}\right)$. Yet, both piles were found to contain significantly lower numbers of bacteria $\left(2.0 \times 10^{5}\right.$ and $\left.3.8 \times 10^{3} \mathrm{cfu} / \mathrm{g}\right)$ during the thermophilic phase of composting as the temperatures peaked. Bacterial numbers increased again in the maturation phase $\left(1.8 \times 10^{6}\right.$ and $\left.1.6 \times 10^{4} \mathrm{cfu} / \mathrm{g}\right)$. These imply that addition of, cow manure, and rice bran were able to improve the degradation process by facilitating the microbial diversity present in the compost throughout the entire composting process. The result agrees with the finding of Liu et al. (2011) that suggests microbial communities in compost changes greatly after meeting with the microbial inoculum. These findings were also in agreement with findings of Hassen et al. (2001). In contrast, bacterial population in pit three $(\mathrm{T})$ differed slightly for the three temperature phases, mesophilic, thermophilic and maturation phase $\left(8.0 \times 10^{4}\right.$, $\left.1.7 \times 10^{4}, 3.510^{4} \mathrm{cfu} / \mathrm{g}\right)$ respectively, thereby resulting in a significant interaction between compost pit and phase $P<0.001$. Because in (T) there was no bulking agent, cow manure and rice bran that will facilitate microbial biodegradation. Pan and Sen, (2013) reported similar population changes when studying the composting process of wheat straw.

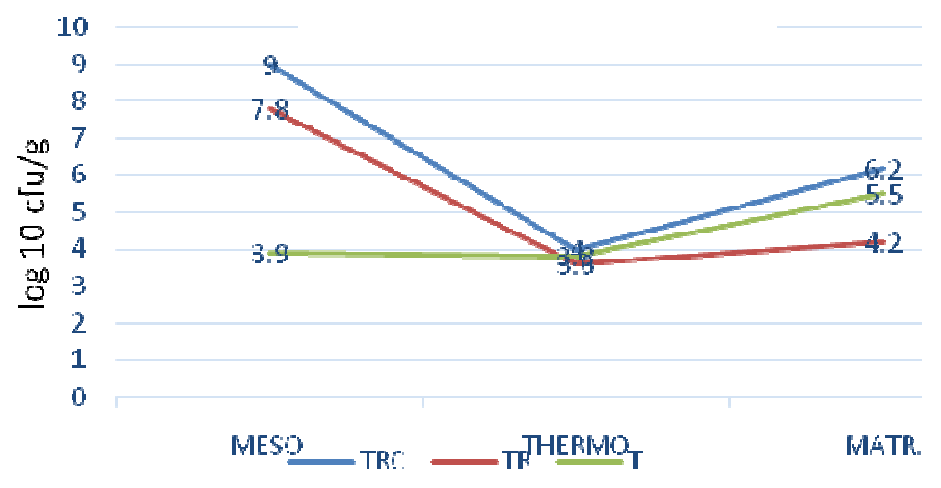

Figure 5: Changes in bacterial population during composting

The Heavy Metal Concentration $(\mathrm{mg} / \mathrm{kg})$ at 60 days of composting

The order of the total metal content in the final composted biomass (TRC, TR and T) were Fe $(2127.78$ - $1911.11 \mathrm{mg} / \mathrm{kg}), \mathrm{Zn}(161.18$ $117.94 \mathrm{mg} / \mathrm{kg})$, Cu $(29.70-23.33 \mathrm{mg} / \mathrm{kg}), \mathrm{Cr}$ (21.54 to $17.85 \mathrm{mg} / \mathrm{kg}), \quad \mathrm{Pb}(10.89$ - 6.09 $\mathrm{mg} / \mathrm{kg})$ and $\mathrm{Cd}(6.61-4.92 \mathrm{mg} / \mathrm{kg})$. All are within the USEPA standard limit of biosolid which are (15000, 39, 2800, 1200 and 300) $\mathrm{mg} / \mathrm{kg}$ for $\mathrm{Cu}, \mathrm{Cd}, \mathrm{Zn}, \mathrm{Cr}$ and $\mathrm{Pb}$ respectively. During composting total heavy metal content decreased as reported by Mahdi et al. (2007). This is as result of leaching in the course of composting during thermophilic phase and could be related to the metal released from decomposed organic matter, an increase in moisture from $58.4 \%$ to $73.5 \%$, a change in other oxidizing and ionic conditions in the medium and therefore increasing the solubility of metals. Some authors suggest that were the potential toxic metal concentrations of compost are higher the leachibility of metal associated with compost is concern. It should consider the role of composting as important environmental sink to illiminate the most liable fraction of metals, mainly during active decomposition phase, indeed, after stabilization phase, metal total concentration is steady indicating that leachibility is stopped, this demonstrates the interest of land application of matured compost. It is also important to allow compost to mature due to the fact that, as compost matures over time, the solubility of heavy metals deceases with a subsequent decease in bioavailabity in the environment. The metals become bound to humic compounds, metals oxides and phosphates in the compost when mixed with the soil (Chaney and Ryan, 1993). 


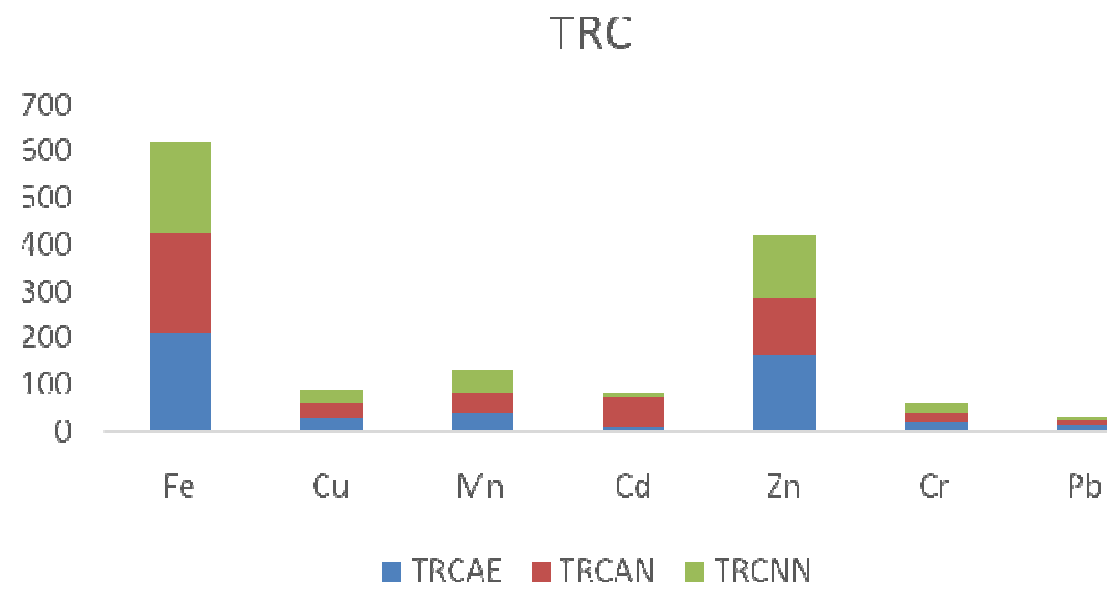

Fig. 6: Heavy Metal Concentration (mg/kg) at 60 days of composting

\section{Compost Maturity/Stability}

For this research four different parameters of maturity test were used, which include (i) color (ii) odour (iii) $\mathrm{CN}$ ratio (iv) germination index. From the results of maturity test at 60 days of composting of different biomass with different treatment it showed that: Tannery sludge, rice bran and cow manure (TRC) were positive for all the parameters assessed, when compared with European standard of compost maturity. Then followed by tannery sludge, rice bran treatment one (TR AE), then tannery sludge, rice bran, cow manure (TRC), this indicates that co-substrating of tannery sludge with rice bran and cow manure plus aeration enhanced the biodegradation of the biomass in the compost system, this finding agrees with that of Fekedu et al., (2013), and Nurul Ain et al., (2014). Compost maturity is the measure of completeness of composting (Butler et al., 2001) maturity is not described by a single method that has been universally applied to all kinds of composting system. Maturity is best assessed by measuring two or more parameters like physical, chemical, plant and microbial activity assay (Logan et al., 1997).

Table 4.6: Result of compost maturity at 60 days of composting

\begin{tabular}{lllll}
\hline $\begin{array}{l}\text { Substrate } \\
\text { combination/ } \\
\text { Treatment }\end{array}$ & Cn & Odour & Colour & $\begin{array}{l}\text { Germ } \\
\text { index (\%) }\end{array}$ \\
\hline TRC & & & & \\
TR & 13 & Earthyl smell & Dark chocolate brown & 80 \\
T & 10 & Earthyl smell & Dark chocolate brown & 80 \\
EU.ST & 6 & High offensive odour & Dark brown & 10 \\
\hline KU: & 13 & Earthyl smell & Dark chocolate brown & $80-100$ \\
\hline
\end{tabular}

Key: EU = European Standard of Compost Maturity

\section{CONCLUSION}

It can be conclude that production of high quality compost can be achieved by using different substrate that is tannery sludge, rice bran and cow manure. The present study indicate the usefulness of different nitrogen amendments and bulking agent for improving composting processes to prepare high quality compost. Co-substrating of tannery sludge with rice bran and cow manure increase in the population size of the microorganism in the biodegradation of the organic matter as shown in initial population of the microorganisms at different treatment but has little effects on accelerating the composting processes, the main factors responsible for accelerating the compositing process are changes of the physicochemical parameters of the raw materials (tannery sludge, rice bran and cow manure), constant aeration of the substrate/raw material used and type of raw waste used for composting processes. 
REFERENCES

Anderson, R.A. (1981). Bioavailability of chromium in soil. Sci. Total Environ., 17:13-29.

Beck-Friis, B., Smårs, S., Jönsson, H., Kirchmann, H., (2001). Emissions of carbon dioxide, ammonia and nitrous oxide from organic household waste in a compost reactor under different temperature regimes. J. Agric. Eng. Res, 78, 423-430.

Bernal, M.P., Alburquerque, J.A, Moral, R. (2009). Composting of animal manures and chemical criteria for compost maturity assessment: a review. BioresourTechnol, 100:5444-5453.

Bernal, M.P., Sanchez-Monedero, M.A. Paredes, C., and Roig, A., (1998). Carbon mineralization from organic wastes at different composting stages during their incubation with soil. Agr. Ecosyst. Environ., 69:175-189.

Bollen D. and Volker G. (1996). The Hygienic Standard of meat handling in the Tamale metropolis. BSc. Dissertation, University for Development Studies, Tamale Ghana 23-29pp.

Boulter, J.I., Boland, G.J, Trevors, J.T. (2001). Compost: a study of the development process and end-product potential for suppression of turfgrass disease. $W \mathrm{~J}$ Microbio Biotech, 16(2):115-134.

Boulter-Bitzer, I.J., Trevors, J.T., Boland, G.J. (2006). A polyphasic approach for assessing maturity and stability in compost intended for suppression of plant pathogen. Appl. Soil Ecol, 34, 6581.

Chaney, R.L. and Ryan, J.A. (1993). Heavy metal and toxic organic pollutants in MSW- composts. In: Hoitink, H.A.J., Keener H.M. (Eds.). Science and engineering of composting: Design, Environmental, Microbiological and Utilization Aspects. Worthington, Ohio: Renaissance Publications, pp. 451-506.

Diaz, S., Crowe, J. D., Olsson, S. (2002). Induction of laccase activity in Rhizoctoniasolani by antagonistic Pseudomonas fluorescens strains and a range of chemical treatments. Appl. Environ. Microbiol. 67(5):2088-2094.

Downer, Dalhammar, G., Borg-Karlson, A. K. (2008). Practical use of quality compost for plant health and vitality improvement. Microbiology of composting Pp 435-444.

Elorrietal, E., M., Dalhammar, G., Borg-Karlson, A. K. (2006). Biological degradation of selected hydrocarbons in an old $\mathrm{PAH} /$ creosote contaminated soil from a gas work site. Appl. Microbiol. Biotechnol. 53(5):619-626.

Eno, J.U., Trenchard, O.I., Joseph A.O., Anthony. O A., Ivara E.E., (2009) "Manual of Soil, Plant and water Analysis": Lagos, Sibon Book Ltd

Fayolle, G. Tamine, A.Y., Robinson, R.K. (2006). Soil Science and Technology. 3rd ed. Cambridge, Woodhead Publishing Limited p. 808.

Fekedu, S., María, G.B., Ingrid, H.F. (2014) Coffee husk composting: An investigation of the process using molecular and non-molecular tools. Waste Management 34 (2014) 642-652

Fliessbatch K.B, Tamine, A.Y., Robinson, R.K. (2006) Microbial diversity in synthetic compost as revealed by PCR- Amplified rRNA sequences from cultivated isolates and extracted DNA. Microbial Ecology. Pp 207-216.

Gomez-Brandon, M., Lazcanoa, C., Domíngueza, J. (2008). The evaluation of stability and maturity during the composting of cattle manure. Chemosphere 70:436-444.

Hassen, A., Belguith, K., Jedidi, N., Cherif, A., Cherif, M., Boudabous, A., (2001). Microbial characterization during composting of municipal solid waste. Bioresour. Technol. 80, 217-225.

Innebrebner, Mazzola, M., Granatstein, D. M., Elfving, D. C., Mullinix, K., Gu, Y. H. (2006).Cultural management of microbial community structure to enhance growth of apple in replant soils. Phytopathology 92(12):1363-1366.

Irshad, M., Eneji, E., Hussain, Z. and Ashraf, M. (2013).Chemical characterization of fresh and composted livestock manures. Journal of Soil Science and Plant Nutrition 13, 115-121.

Lisk, D.J., Gutenmann, W.H., Rutzke, M., Kuntz, H.T., and Chu, G. (1992). Toxic materials in the soil. Arch. Environ. Contam. Toxicol., 22:190-194.

Liu, J., Xu, X. H., Li, H. and Xu, Y. (2011). Effect of microbiological inocula on chemical and physical properties and microbial community of cow manure compost. Biomass and Bioenergy 35, 3233-3439.

Logan, T.J., He, T.X. andTraina S.J. (1992). Chemical Properties ofMunicipal Solidwastecomposts. J.Environ. Qual., 21:318-329 
Logan, T.J., Lindsay, B.J., Goins, L.E., \& Ryan, J.A. (1997). Field assessment of sludge bioavailabilty to crops: Sludge response. J. Environ. Qual. 26, 534550.

Mahdi, A., AZNI, I., SYED, S. R. O. (2007). Physicochemical Characterization of Compost of the Industrial Tannery Sludge. Journal of Engineering Science and Technology Vol. 2, No. 1, 81-94

NurulAin, A N., Ibrahim M.H., Hariz, A., NurAlyani, S. (2011). Microbial population assessment during IMOcomposting production: Malaysian Journal of Microbiology, Vol 11(1) 2015, pp. 47-53

Ouatmane, A., Provenzano, M.R., Hafidi, M., and Senesi, N. (2000). Compostmaturity assessment using calorimetry, spectroscopy and chemical analysis. Compost Sci.Utilisat. 8, 124-134.

Pan, I., and Sen, S.K. (2013). Microbial and Physico-chemical Analysis of Composting Process of Wheat straw: Indian Journal of Biotechnology vol. 12 January, 2013. Pp 120-128

Pourcher, K., Jay, Y., Mount, .J. (2005). Modern Food Technology. Aspen Pub. Inc. Grathernburg, Mary land. Pp . 113128.
Riegel, E.R. (1949). Leather gelatin and glue. In: Industrial Chemistry. Reinhold Publisher Co., New York, p. 759-765.

Ryckeboer, J., Mergaert, J., Coosemans, J., Deprins, K., Swings, J. (2003). Microbiological Aspects of biowaste during composting in a monitored compost bin. J ApplMicrobiol, 94(1):127-137.

Sánchez-Monedero, M.A., Roig, A., Paredes, C., Bernal, M.P., (2001). Nitrogen transformation during organic waste composting by the Rutgers system and its effects on $\mathrm{pH}, \mathrm{EC}$ and maturity of the composting mixtures. Bioresour. Technol. 78, 301-308.

Senesi, N. (1989). Composted materials as organic fertilizers. Sci. Total Environ., 82:521-542.

Walkey, A. and Black C.A (1934). An examination of the Degtjareff method for determining soil organic matter and a proposed modification of the chronic acidification method. Soil Sci. , 37: 2938.

Zhu, N. (2007).Effect of low C/N ratio on aerobic composting of swine manure with rice straw. Bioresource Technology 98, 9-13.

Zucconi F, Forte M, Monaco A, De Bartoldi M (1981). Biological evaluation of compost maturity. Biocycle, 22:27-29. 